\title{
ANALISA PENGARUH FAKTOR-FAKTOR PEMBIAYAAN MUDHARABAH TERHADAP PROFITABILITAS PADA BANK UMUM SYARIAH PERIODE TAHUN 2013-2017
}

Yanti ${ }^{1}$, Neneng Setia Asih ${ }^{2}$

Universitas Buana Perjuangan Karawang yanti@ubpkarawang.ac.id

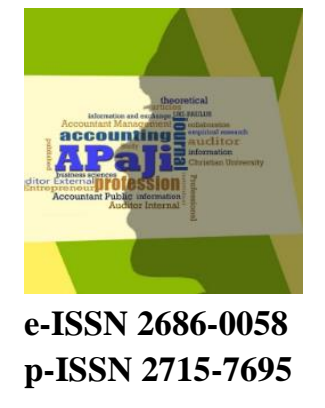

Informasi Artikel Tanggal masuk 20 Desember 2019 Tanggal revisi 30 Desember 2019 Tanggal diterima 26 Januari 2020

Kata Kunci: Mudharabah Financing ${ }^{1}$ Profitability $^{2}$
Abstract: This study aims to determine the effect of mudharabah financing factors on simultaneous profitability in sharia commercial bank in Indonesia for the period 2013-2017. financing mudharabah can increase the profitability of islamic banks with mutual benefits between the customer and the bank. yhis research exanines the influence of mudharabah financing factors on profitability. Namaly in the from of FDR, BOPO and NPF in islamic commercial banks in Indonesia. By using quantitative research and analiysis in this study by using secondary date from quarterly financial statements of commercial banks that have been published annually. In this study the model used by descriptive statistical tests, colmogorof smirnov normality test, classic assumption test, multiple regression test, formal t test, $f$ test semultaneously an $R$ squaere test of determination. This study uses ROE in calculating profitability. The results of this study indicate that the variabels FDR, BOPO, and NPF simultaneously have a significant effect on profitability in islamic commercial banks in Indonesia for the period 20132017. From the results of this study that FDR, BOPO, and NPF have a major influence on the factors of mudharabah financing in increasing the profitability of sharia comercialbank in Indonesia.

Abstrak: Penelitian ini bertujuan untuk mengetahui pengaruh faktor-faktor pembiayaan mudharabah terhadap profitabilitas pada bank umum syariah periode 2013-2017. Pembiayan mudharabah ini dapat meningkatkan profitabilitas pada bank umum syariah dengan saling menguntungkan antara pihak nasabah maupun pihak bank. Penilitian ini meniliti tentang pengaruh faktor-faktor pembiayaan mudharabah terhadap profitabilitas, yaitu berupa FDR, BOPO dan NPF pada bank umum syariah di Indonesia. Dengan menggunakan penelitian kuantitatif dan penelitian ini menggunakan data sekunder dari laporan keuangan triwulan bank umum syariah yang telah di publikasi setiap tahunnya. Dalam penelitian ini model yang digunakan oleh peneliti menggunakan tekhnik pengolahan data adalah dengan uji statistik deskriptif, uji normalitas kolmogorof smirnov, uji asumsi klasik, uji regresi berganda, uji $\mathrm{t}$ seacara parsial, uji $\mathrm{f}$ secara simultan dan uji $\mathrm{R}$ square determinasi. Penelitian ini menggunakan ROE dalam menghitung profitabilitas. Hasil dari penelitian ini menunjukan bahwa variabel FDR, BOPO, dan NPF secara simultan berpengaruh signifikan terhadap profitabilitas pada bank umum syariah di Indonesia periode 2013-2017. Dari hasil penelitian ini bahwa FDR, BOPO dan NPF mempunyai pengaruh besar terhadap faktor-faktor pembiayaan mudharabah dalam meningkatkan profitabilitas bank umum syariah di Indonesia. 


\section{PENDAHULUAN}

Dalam perekonomian dunia meningkat pesat dengan jumlah negara yang semakin maju dalam hal ini mempunyai hubungan dengan dunia keuangan dan perbankkan. Dalam era globalisasi pertumbuhan ekonomi yang mempunyai tingkat naik dan turun nya keuangan suatu negara dalam hal ini tergantung baik dan buruknya keadaan keuangan suatu negara. Saat perekonomian Indonesia yang menurun dan sulitnya mendapatkan pekerjaan maka untuk memenuhi taraf hidup masyarakat banyak yang beralih membuka usaha. Kegiatan usaha yang sudah di jalankan cukup lama membutuhkan modal yang cukup besar, sehingga pengusaha bekerjasama dengan bank untuk menambahkan modal usahanya.

Bank syariah di Indonesia lahir sejak tahun 1992, bank syariah pertama di Indonesia adalah bank muamalat Indonesia. Bank syariah merupakan bank yang kegiatannya mengacu pada hukum islam, dan dalam kegiatannya tidak membebankan bunga maupun tidak membayar bunga kepada nasabah, imbalan yang di terima oleh bank syariah maupun yang dibayarkan kepada nasabah dan bank. Perjanjian (akad) yang terdapat di bank syariah harus tunduk pada syarat dan rukun akad sebagaimana yang di atur dalam islam. Menurut Drs. Ismail, MBA.,Ak (2011:31).

Pembiayaan adalah penyediaan uang atau tagihan yang di persamakan dengan itu berdasarkan persetujuan atau kesepakatan antara bank dengan pihak lain yang mewajibkan pihak dibiayai untuk mengembalikan uang atau tagihan tersebut setelah jangka waktu tertentu dengan imbalan atau bagi hasil. Menurut Kasmir (96:2008). akad mudharabah merupakan akad salah suatu transaksi investasi yang berdasarkan kepercayaan antara pihak nasabah dan bank. Dalam kepercayaan adalah salah satu unsur terpenting dalam akad mudharabah, yaitu kepercayaan dari pemilik dana kepada pemilik dana. Menurut Sri nurhayati, Wasilah (128:2008).

Profitabilitas yang menggunakan rasio ROE (retrun on equity) suatu bank syariah dapat di pengaruhi oleh berbagai faktor, akan tetapi dalam hal ini penulis ingin meneliti dan mengetahui tentang pengaruh faktor-faktor pembiayaan mudharabah terhadap profitabillitas bank umum syariah dengan mengukur rasio menggunakan $R O E$ (retrun on equity) pada bank umum syariah Indonesia.

Berdasarkan latar belakang tersebut bahwa penulis tertarik dalam melakukan penelitian dengan judul ( Pengaruh faktor-faktor pembiayaan mudharabah terhadap bank umum syariah di Indonesia periode 2013-2017).

Kerangka berfikir merupakan model konseptual tentang bagaimana teori hubungan dengan berbagai faktor yang telah diidentifikasi sebagai masalah yang penting. Kerangka pemikiran yang baik akan menjelaskan secara teoritis peraturan antara variabel independen dan dependen. Berdasarkan landasan teori di atas tersebut dapat di susun kerangka pemikiran sebagai berikut. 
Gambar

Gambar kerangka pemikiran

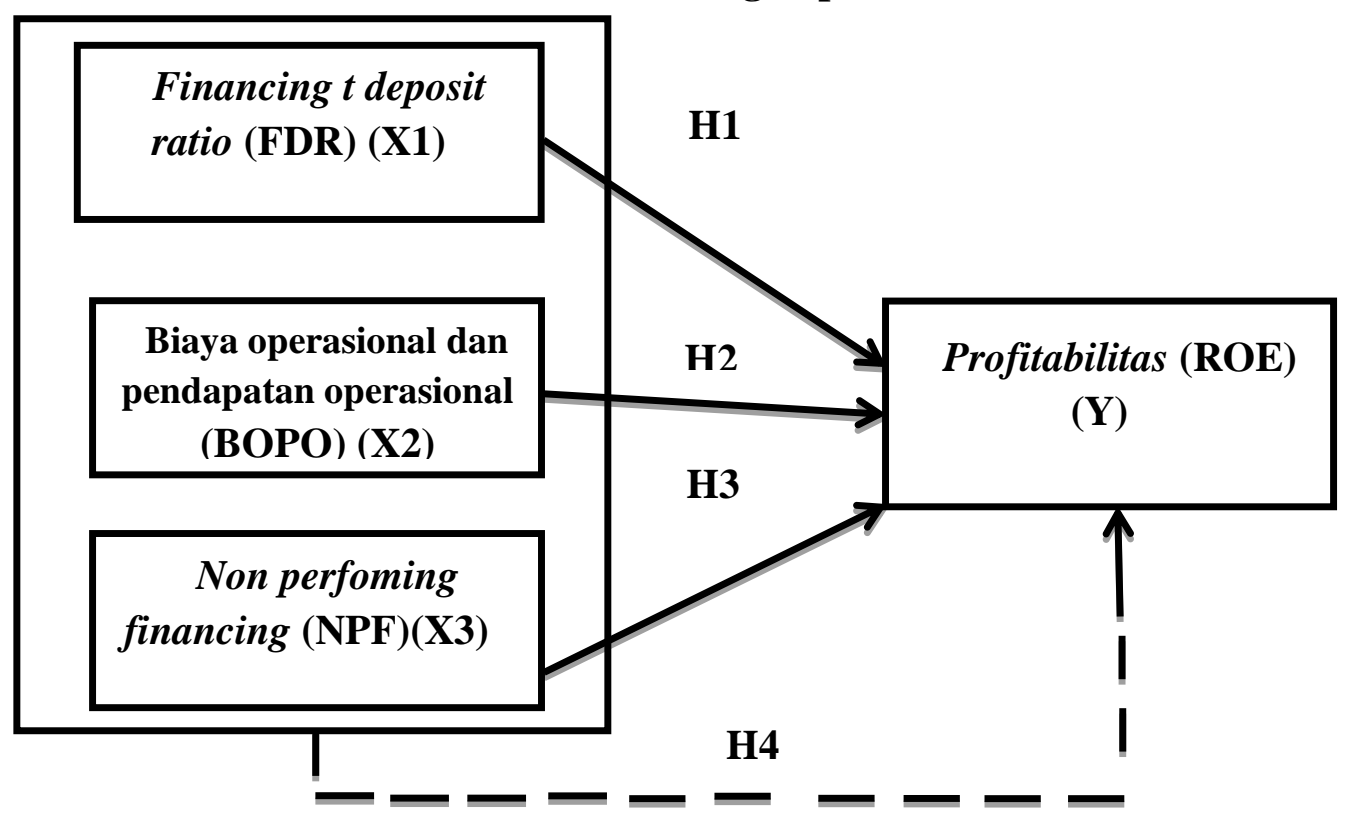

Keterangan gambar :

a. Variabel Independen untuk penelitian ini adalah Financing deposit ratio (FDR) (X1), Biaya operasional dan pendapatan operasional (BOPO) (X2), Non perfoming financing(NPF) (X3).

b. Variabel dependen dalam penelitian ini adalah Profitabilitas Return On Equity (ROE).

Peneliti meneliti tentang seberapa besar atau ada tidaknya pengaruh variabel independen (FDR, BOPO, NPF) terhadap variabel dependen Profitabilitas (ROE).

Menurut prof Dr Abuzar Asra (2014:69) hipotesis adalah dugaan atau kesimpulan sementara terhadap sesuatu (parameter populasi) yang dapat benar (true) atau tidak benar (non true). Dalam statistika, hipotesis tersebut yang bisa di uji secara empiris (tastable hypotesis) di sebut sebagai hipotesis statistik (statistical hypotesis). Berdasarkan kerangka pemikiran:

Menurut Dendawijaya (2003:67) dalam Nasution, Sri mutaha (2017) FDR ( Financing Deposit Ratio) "merupakan kemampuan perusahaan atau bank dalam membayar kemabali penarikan dana yang di lakukan deposan dengan mengendalikan kredit yang di berikan sebagai sumber likuiditasnya di sebut loan to deposit ratio.

H01 : Financing to deposit (FDR)tidak berpengaruh signifikan terhadap profitabilitas Retrun on Equity (ROE) pada bank umum syariah Indonesia periode 2013-2017

Ha1 : Financing to deposit (FDR)berpengaruh signifikan terhadap profitabilitas Retrun on Equity (ROE) pada bank umum syariah Indonesia periode 2013-2017.

Menurut Ponco (2008:19) dalam Nasution, Sri mutaha (2017) merupakan efesiensi operasi yang di ukur dengan membandingkan total biaya operasi dengan total pendapatan operasi yang di sebut dengan BOPO. Rasio BOPO bertujuan untuk mengukur kemampuan 
pendapatan operasional dalam menutup biaya operasional. Tingkat efesiensi bank dalam menjalankan operasinya, berpengaruh terhadap tingkat pendapatan yang di hasilkan oleh bank, jika kegiatan operasional dilakukan dengan efisien, maka pendapatan yang di hasilkan bank akan meningkat.

H02 : Biaya operasional dan pendapatan operasional (BOPO) tidak berpengaruh signifikan terhadap profitabilitas Retrun on Equity (ROE) pada bank umum syariah di Indonesia periode 2013-2017

Ha2 : Biaya operasional dan pendapatan operasional (BOPO) berpengaruh signifikan terhadap profitabilitas Retrun on Equity (ROE) pada bank umum syariah di Indonesia periode 2013-2017

Menurut Ahmad apandi (2015) NPF (Non perfoming Financing) adalah suatu keadaan di mana nasabah sudah tidak sanggup lagi membayar seluruh kewajibannya kepada bank seperti yang telah di perjanjikan. Non perfoming financing atau pembiayaan bermasalah atau dalam bank konvensional biasa di sebut dengan NPL ( Non Perfoming Loan) adalah suatu pembiayaan yang mengalami masalah dalam pengembaliannya bisa dikarenakan faktor eksternal pihak nasabah maupun internal dari bank itu sendiri.

H03 : Non perfoming financing (NPF) tidak berpengaruh signifikan terhadap profitabilitas Retrun on Equity (ROE) pada bank umum syariah di Indonesia periode 2013-2017

Ha3 : (Non perfoming financing (NPF) berpengaruh signifikan terhadap profitabilitas Retrun on Equity (ROE) pada bank umum syariah di Indonesia periode 2013-2017.

H04 : FDR, BOPO dan NPFsecara simultan tidak berpengaruh signifikan terhadap profitabilitas Retrun on Equity (ROE) pada bank umum syariah di Indonesia periode 20132017

Ha4 : FDR, BOPO dan NPFsecara simultan berpengaruh signifikan terhadap profitabilitas Retrun on Equity (ROE) pada bank umum syariah di Indonesia periode 2013-2017

\section{METODE PENELITIAN}

Menurut Sugiyono (2013:2) Metode penelitian pada dasarnya merupakan cara ilmiah untuk mendapatkan data dengan tujuan dan kegunaan tertentu. Menurut Sugiyono (2013:13) Metode kuantitatif merupakan metode penelitian yang berlandaskan pada filsafat positivisme, digunakan untuk meneliti pada populasi dan sampel tertentu, teknik pengambilan sampel pada umumnya dilakukan secara random, pengumpulan data menggunakan instrumen penelitian.

Metode penelitian yang digunakan oleh peneliti adalah menggunakan studi dokumentasi dan kepustakaan yang di peroleh melalui laporan keuangan yang berhubungan dengan bank umum syariah. Sedangkan metode penelitian data yang digunakan yaitu metode deskriptif dengan pendekatan kuantitatif, yaitu dengan mengumpulkan, menyusun, meneliti, dan menginterprestasikan sehingga memberikan keterangan lengkap bagi pemecahan masalah yang di hadapi pada subjek penelitian mengenai pengaruh faktor-faktor pembiayaan mudharabah terhadap profitabilitas pada bank syariah.

Peneliti menggunakan regresi linier berganda dengan menggunakan rumus sebagai berikut: 


$$
\mathrm{Y}=\mathrm{b} 1 \times 1+\mathrm{b} 2 \times 2+\mathrm{b} 3 \times 3+\mathrm{e}
$$

Dimana:

$\mathrm{Y} \quad=$ Profitabilitas $(\mathrm{ROE})$

$\mathrm{X} 1=$ FDR (Financing Deposit Ratio)

$\mathrm{X} 2=\mathrm{BOPO}$ (Biaya Operasional dan Pendapatan Operasional)

$\mathrm{X} 3=\mathrm{NPF}$ (Non Perfoming Financing)

e $\quad=$ eror

Menurut Sugiyono (2016:80) populasi adalah wilayah generalisasi yang terdiri atas obyek/subyek yang mempunyai kualitas dan karakteristik tertentu yang telah ditetapkan oleh peneliti untuk dapat di pelajari dan kemudian di tarik kesimpulannya. Jadi populasi bukan hanya orang, tetapi juga obyek dan benda-benda alam dan sebagainya. Populasi juga bukan hanya sekedar jumlah yang ada pada obyek/subyek yang dipelajari, tetapi meliputi seluruh karakteristik/sifat yang dimiliki oleh subyek itu. Populasi yang di gunakan oleh peneliti untuk penelitian ada beberapa bank umum syariah yang ada di Indonesia ada 12 bank umum syariah, diantaranya:

Daftar Bank umum syariah di Indonesia yang di jadikan populasi

\begin{tabular}{|l|l|}
\hline No & Nama Bank syariah \\
\hline 1 & Bank BNI syariah \\
\hline 2 & Bank mega syariah \\
\hline 3 & Bank muamalat Indonesia \\
\hline 4 & Bank syariah Mandiri \\
\hline 5 & Bank BCA syariah \\
\hline 6 & Bank BRI syariah \\
\hline 7 & Bank jabar banten syariah \\
\hline 8 & Bank panin syariah \\
\hline 9 & Bank syariah Bukopin \\
\hline 10 & Bank victoria syariah \\
\hline 11 & Bank maybank syariah \\
\hline 12 & Bank btpn syariah \\
\hline
\end{tabular}

Diolah sendiri dari sumber bank umum syariah di Indonesia.

Menurut Sugiyono (2016:81) sampel adalah bagian dari jumlah dan karakteristik yang dimiliki oleh populasi tersebut. Bila populasi besar, dan peneliti tidak mungkin mempelajari semua yang ada pada populasi, misalnya karena keterbatasan dana, tenaga dan waktu, maka peneliti dapat menggunakan sampel yang di ambil dari populasi itu. Apa yang di pelajari dari sampel itu, kesimpulannya akan dapat di berlakukan untuk populasi. Untuk sampel yang diambil dari populasi harus betul-betul representatif (mewakili).

Dari hasil populasi di atas dapat di ambil populasi yang sesuai dengan kriteria yang di perlukan oleh setiap variabel yaitu laporan keuangan triwulan periode 2013-2017, ada 5 bank umum syariah yang di jadikan sampel dan memenuhi kriteria sebagai berikut: 


\section{Tabel}

Daftar Bank umum syariah di Indonesia yang di jadikan sampel

\begin{tabular}{|l|l|}
\hline No & Nama Bank syariah \\
\hline 1 & Bank BNI syariah \\
\hline 2 & Bank Muamalat syariah \\
\hline 3 & Bank Mandiri syariah \\
\hline 4 & Bank BCA syariah \\
\hline 5 & BankVictoria syariah \\
\hline
\end{tabular}

Diolah sendiri dari sumber bank umum syariah Indonesia periode 2013-2017.

Menurut Sugiyono (2016:81) teknik sampling merupakan teknik pengambilan sampel yang akan di gunakan dalam penelitian, terdapat berbagai teknik sampling yang digunakan seperti probability sampling.

Jenis data yang digunakan oleh peneliti ini adalah data sekunder dan merupakan data cross section (data yang dikumpulkan dalam satu waktu terhadap banyak individu). Data kuantitatif adalah data-data yang disajikan dalam bentuk angka-angka. Dalam penelitian ini, penulis menggunakan data kuantitatif berupa laporan keuangan triwulan bank syariah pada periode 2013-2017.

Sumber data yang digunakan dalam penelitian ini adalah data sekunder. Data sekunder merupakan data yang diperoleh secara tidak langsung, dimana perolehan tersebut berupa data yang sudah jadi. Sumber data yang di peroleh oleh peneliti dalam penelitian ini di ambil secara tidak langsung atau melalui media perantara berupa laporan keuangan bank syariah. Media perantara tersebut berupa situs website resmi bank syariah indonesia.

Peneliti menggunakan studi kepustakaan dan metode dokumentasi. Studi kepustakaan adalah pengumpulan data yang dilakukan dengan menghimpun informasi yang relevan dengan topik atau masalah yang akan diteliti atau sedang diteliti. Metode dokumentasi adalah pengumpulan data yang akan dilakukan menghimpun informasi itu diperoleh dari buku-buku ilmiah, jurnal.

Metode dokumentasi dalam penelitian ini dilakukan dengan cara mengumpulkan data berupa laporan keuangan triwulan di situs resmi bank syariah di Indonesia pada periode 2013-2017.

Menurut prof Dr. Sugiyono (2016:147) statistika deskriptif adalah statistika yang digunakan untuk menganalisis data dengan cara mendeskriptifkan atau menggambarkan data yang telah terkumpul sebagaimana adanya tanpa bermaksud membuat kesimpulan yang terkumpul sebagaimana adanya tanpa bermaksud membuat kesimpulan yang berlaku umum atau generalisasi. Tetapi bila penelitian dilakukan sampel, maka analisisnya dapat menggunakan statistika deskriptif maupun inferensial.

Menurut Dhian dayinta pratiwi (2012) metode yang digunakan adalah model regresi linier berganda yang persamaannya dapat di tuliskan sebagai berikut:

$\mathrm{Y}=\mathrm{a}+\mathrm{b} 1 \mathrm{X} 1+\mathrm{b} 2 \mathrm{X} 2+\mathrm{b} 3 \mathrm{X} 3+\mathrm{e}$

Dimana:

$\mathrm{Y}=$ Profitabilitas $(\mathrm{ROE})$

$\mathrm{a}=$ Konstanta 


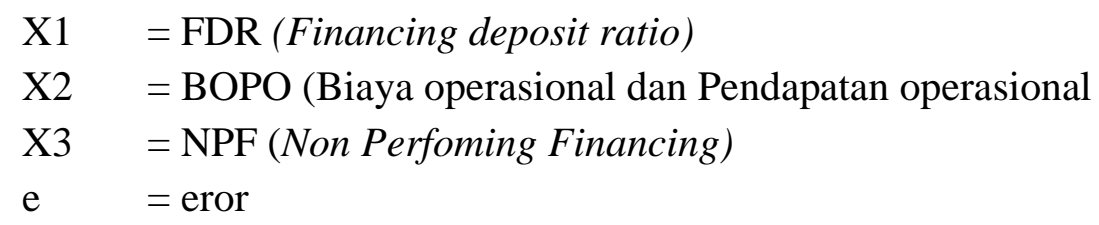

Menurut Ghozali (2011:81) Uji t digunakan untuk mengetahui seberapa jauh kemampuan suatu variabel indevenden secara individual dalam mmenerangkan variasi variabel dependen. Metode ini dilakukan pada persamaan regresi yang diperoleh hubungan masing-masing variabel bebasnya dengan batas normal atau koefisien alfanya (5\% atau 10\%).

Langkah-langkah analisis dalam pengujian hipotesis terhadap koefisien regresi adalah sebagai berikut:

a. Perumusan hipotesis

$\mathrm{H} 0: \quad \mathrm{b} 1=0$

$\mathrm{b} 2=0$

Ha : $\quad b 1 \neq 0$

$\mathrm{b} 2 \neq 0$

b. Penentuan nilai kritis. Nilai kritis dalam pengujian hipotesis terhadap koefisien regresi dapat ditentukan dengan menggunkan tabel ditribusi normal dengan memperhatikan tingkat signifikan $(\alpha)$ dan banyaknya sampel yang digunakan.

c. Nilai thitung masing-masing koefisien regresi dapat diketahui dari hasil perhitungan komputer.

d. Pengambilan keputusan dilakukan berdasarkan perbandingan nilai thitung (nilai kritis) sesuai dengan tingkat signifikansi yang digunakan.

Menurut Latan dan Tamalagi (2013:81) Uji F pada dasarnya bertujuan untuk mengetahui apakah semua variabel independen yang dimaksudkan dalam model regresi sudah tepat digunakan terhadap variabel dependen ataukah tidak tepat. Jika nilai signnifikan yang dihasilkan uji F p $<0.05$, maka dapat disimpulkan bahwa semua variabel independen model yang digunakan sudah tepat terhadap variabel dependen.

Cara lain untuk menguji signifikansi uji $\mathrm{F}$ adalah dengan membandingkan $\mathrm{F}$ adalah dengan membandingkan Fstatistik dengan Ftabel, jika Fstatistik >Ftabel, maka dapat disimpulkan bahwa semua variabel independen menggunakan model yang sudah tepat terhadap variabel dependen.

Ghozali (2011:97) Koefisien determinasi $\left(\mathrm{R}^{2}\right)$ pada intinya mengukur seberapa jauh kemampuan model dan menerangkan variasi variabel dependen. Nilai koefisien determinasi antar 0-1. Nilai $\left(\mathrm{R}^{2}\right)$ yang kecil berarti kemampuan variabel-variabel independen dalam menjelaskan variasi variabel dependen sangat terbatas. Nilai yang mendekati satu berarti variabel-variabel inependen memberikan hampir semua informasi yang di butuhkan untuk memprediksi variasi variabel dependen.

Ciri-ciri koefisien determinasi menurut Lind (2014:123) yaitu:

1. Dilambangkan dengan huruf capital $R$ kuadrat. Dengan kata lain, di tulis dengan $\left(\mathrm{R}^{2}\right)$ karena berperilaku seperti koefisien korelasi kuadrat. 
2. Berkisar dari 0 hingga 1 . Nilai yang mendekati 0 menunjukkan hubungan lemah antara sekelompok variabel bebas dengan variabel terikatnya. Nilai mendekati 1 menunjukkan hubungan yang kuat.

3. Tidak dapat bernilai negatif. Sembarang angka yang dikuadratkan atau dipangkatkan dua tidak bisa bernilai negatif

4. Mudah di tafsirkan. Karena $\left(\mathrm{R}^{2}\right)$ merupakan nilai di antara 0 dan 1 , maka ditafsirkan, dibandingkan dan dipahami.

Koefisien determinasi $\left(\mathrm{R}^{2}\right)$ digunakan untuk mengetahui sampai sejauh mana ketepatan atau kecocokan garis regresi yang terbentuk dalam mewakili kelompok data hasil observasi. Koefisien determinasi menggambarkan bagian dari total yang dapat diterangkan oleh model. Semakin besar nilai $\left(\mathrm{R}^{2}\right)$ (mendekati 1 ), maka ketepatannya dikatakan semakin baik.

\section{HASIL DAN PEMBAHASAN}

Dalam penelitian ini mempunyai populasi sebanyak 12 bank umum syariah dengan sampel 5 bank. Sampel dalam penelitian ini adalah bank umum syariah dari periode 20132017. Variabel yang termasuk di dalamnya adalah FDR, BOPO, dan NPF merupakan variabel independen dan profitabilitas termasuk variabel dependen. Laporan keuangan yang digunakan adalah laporan triwulan periode 2013-2017, dengan jumlah data sebanyak 100 sampel data. Penelitian ini menggunakan sekunder dengan memperoleh data dari bank umum syariah yang telah di publikasikan ke dalam situs wabsite masing-masing bank yaitu www.bnisyariah.co.id;www.bankmuamalatsyariah.co.id;www.banksyariahmandiri.co.id; www.bcasyariah.co,id; www.viktoriasyariah.co.id. Penulis menggunakan aplikasi spss (statistic production solution service) versi 16 untuk mengolah data penelitian.

\section{Tabel}

Uji statistik deskriptif X1, X2, X3, Y

Descriptive Statistics

\begin{tabular}{|l|r|r|r|r|r|}
\hline & N & Minimum & Maximum & \multicolumn{1}{c|}{ Mean } & \multicolumn{1}{c|}{ Std. Deviation } \\
\hline FDR & 100 & 77,75 & 110,13 & 90,8404 & 7,58867 \\
BOPO & 100 & 62,24 & 177,90 & 94,2642 & 15,33498 \\
NPF & 100 &, 00 & 6,44 & 2,4148 & 1,66812 \\
PROFITABILITAS & 100 & $-62,71$ & 90,29 & 8,2796 & 19,48362 \\
Valid N (listwise) & 100 & & & & \\
\hline
\end{tabular}

Berdasarkan tabel dapat di simpulkan bahwa $\mathrm{n}$ merupakan jumlah data pengamatan yang di gunakan sebanyak 100. Tabel di atas memperlihatkan rata-rata (mean) FDR (Financing Deposit Ratio) periode 2013-2017 sebesar 90,8404 dengan standar deviasi sebesar 7,58867 dan maximum FDR tertinggi 110,13.

Tabel di atas memperlihatkan rata-rata (mean) BOPO (Beban operasional dan Pendapatan operaasional) periode 2013-2017 sebesar 94,2642 dengan standar deviasi sebesar 15,33498 dan maximum bopo tertinggi sebesar 177,90. 
Dari tabel di atas memperlihatkan rata-rata (mean) NPF (Non perfoming financing) periode 2013-2017 sebesar 2,4148 dengan standar deviasi sebesar 1,68812 dan maximum NPF tertinggi sebesar 6,44.

Dari tabel di atas memperlihatkan rata-rata (mean) profitabilitas periode 2013-2017 sebesar 8,2796 dengan standar deviasi sebesar 19,48362 dan maximum profitabilitas tertinggi sebesar 90,29.

\section{Tabel}

Uji normalitas data

One-Sample Kolmogorov-Smirnov Test

\begin{tabular}{|ll|r|r|r|r|}
\hline & & \multicolumn{1}{|c|}{ FDR } & \multicolumn{1}{|c|}{ BOPO } & \multicolumn{1}{c|}{ NPF } & PROFITABILITAS \\
\hline $\mathrm{N}$ & & 100 & 100 & 100 & 100 \\
Normal & Mean & 90,8404 & 94,2642 & 2,4148 & 8,2796 \\
Parameters & Std. Deviation & 7,58867 & 15,33498 & 1,66812 & 19,48362 \\
Most Extreme & Absolute &, 093 &, 271 &, 140 &, 255 \\
Differences & Positive &, 093 &, 271 &, 140 &, 255 \\
& Negative &,- 061 &,- 165 &,- 107 &,- 250 \\
Kolmogorov-Smirnov Z &, 930 & 2,715 & 1,403 & 2,549 \\
Asymp. Sig. (2-tailed) &, 353 &, 000 &, 039 &, 000 \\
\hline
\end{tabular}

Sumber: spss versi 16

Berdasarkan dari tabel di atas tingkat signifikan dari uji normalitas data FDR (Financing deposit Ratio) sebesar 0,335 dan selanjutnya di bandingkan tingkat signifikan yang tetapkan sebesar 0.05, berdasarkan perbandingan tersebut bahwa 0,353 lebih besar dari $>$ 0,05 maka dapat disimpulkan bahwa Ha berdistribusi normal atau data FDR (Financing deposit ratio) merupakan data berdistribusi normal.

Berdasarkan dari tabel tingkat signifikan dari uji normalitas data BOPO (Biaya operasional dan pendapatan ) sebesar 0,000 dan selanjutnya di bandingkan tingkat signifikan yang tetapkan sebesar 0.05, berdasarkan perbandingan tersebut bahwa 0,000 lebih besar dari $<$ 0,05 maka dapat disimpulkan bahwa Ho berdistribusi tidak normal atau data BOPO (Biaya operasional dan pendapatan operasional)merupakan data berdistribusi tidak normal.

Berdasarkan dari tabel tingkat signifikan dari uji normalitas data NPF (Non Perfoming Financing) sebesar 0,039 dan selanjutnya di bandingkan tingkat signifikan yang tetapkan sebesar 0.05, berdasarkan perbandingan tersebut bahwa 0,039 lebih besar dari $<0,05$ maka dapat disimpulkan bahwa Ho berdistribusi tidak normal atau data NPF (Non Perfoming Financing) merupakan data berdistribusi tidak normal.

Berdasarkan dari tabel tingkat signifikan dari uji normalitas data Profitabilitassebesar 0,000 dan selanjutnya di bandingkan tingkat signifikan yang tetapkan sebesar 0.05, berdasarkan perbandingan tersebut bahwa 0,000 lebih besar dari $<0,05$ maka dapat disimpulkan bahwa Ho berdistribusi tidak normal atau data profitabilitasmerupakan data berdistribusi tidak normal.

Berdasarkan hasil kolmogorov smirnov bahwa variabel BOPO dan profitabilitas berdistribusi tidak normal. Maka data yang berdistribusi normal menggunakan cara rumus transformasi spss yang di lakukan dengan SQRT yang merupakan rumus dengan akar kuadrat sebagai berikut: 
Uji normalitas data

One-Sample Kolmogorov-Smirnov Test

\begin{tabular}{|ll|r|r|r|r|}
\hline & & FDR_SQRT & BOPO_SQRT & NPF_SQRT & PROFITABILITAS_SQRT \\
\hline $\mathrm{N}$ & & 76 & 76 & 76 & 76 \\
Normal & Mean & 9,4040 & 9,5581 & 1,3408 & 2,4044 \\
Parameters $^{\mathrm{a}}$ & Std. Deviation &, 33505 &, 27535 &, 67456 &, 89857 \\
Most Extreme & Absolute &, 104 &, 113 &, 150 &, 123 \\
Differences & Positive &, 104 &, 084 &, 094 &, 118 \\
& Negative &,- 080 &,- 113 &,- 150 &,- 123 \\
Kolmogorov-Smirnov Z &, 907 &, 982 & 1,308 &, 073 \\
Asymp. Sig. (2-tailed) &, 383 &, 290 &, 065 &, 200 \\
\hline
\end{tabular}

a. Test distribution is Normal.

Hasil dari tabel tingkat signifikan dari uji normalitas data BOPO (Biaya operasional dan pendapatan operasional) sebesar 0,290 dan selanjutnya di bandingkan dengan tingkat signifikan yang telah di tetapkan sebesar 0,05 , berdasarkan perbandingan tersebut bahwa 0,290 lebih besar dari > 0,05 maka dapat disimpulkan bahwa Ha berdistribusi normal atau data biaya operasional dan pendapatan operasionalmerupakan data berdistribusi normal.

Berdasarkan dari tabel 4.3 tingkat signifikan dari uji normalitas data profitabilitas sebesar 0,200 dan selanjutnya di bandingkan dengan tingkat signifikan yang telah di tetapkan sebesar 0,05, berdasarkan perbandingan tersebut bahwa 0,200 lebih besar dari > 0,05 maka dapat disimpulkan bahwa Ha berdistribusi normal atau data profitabilitas merupakan data berdistribusi normal.

Menurut V.Wiratna sujarweni (2016:230) uji multikolinearitas diperlukan untuk mengetahui ada tidaknya variabel independen yang memiliki kemiripan antar variabel independen dalam suatu model. Kemiripan antara variabel independen akan mengakibatkan korelasi yang sangat kuat. Selain itu untuk uji ini juga untuk menghindari kebiasaan dalam proses pengambilan keputusan mengenai pengaruh pada uji persial masing-masing variabel independen terhadap variabel dependen. Jika VIF yang di hasilkan diantara 1-10 maka tidak terjadi multikoleniaritas dan dapat di lihat pada tabel sebagai berikut:

\section{Tabel Uji Multikoleniaritas}

\section{Coefficients $^{\mathrm{a}}$}

\begin{tabular}{|c|c|c|c|c|c|c|c|c|}
\hline \multirow{2}{*}{\multicolumn{2}{|c|}{ Model }} & \multicolumn{2}{|c|}{$\begin{array}{c}\text { Unstandardized } \\
\text { Coefficients } \\
\end{array}$} & \multirow{2}{*}{$\begin{array}{c}\begin{array}{c}\text { Standardized } \\
\text { Coefficients }\end{array} \\
\text { Beta }\end{array}$} & \multirow[b]{2}{*}{$\mathrm{t}$} & \multirow[b]{2}{*}{ Sig. } & \multicolumn{2}{|c|}{ Collinearity Statistics } \\
\hline & & $\mathrm{B}$ & Std. Error & & & & Tolerance & VIF \\
\hline \multirow[t]{4}{*}{1} & (Constant) & 29,382 & 3,094 & & 9,495 &, 000 & & \\
\hline & FDR_SQRT &,- 075 & ,211 &,- 028 &,- 356 & ,723 & ,955 & 1,047 \\
\hline & BOPO_SQRT & $-2,824$ & ,292 &,- 865 & $-9,672$ & ,000 &, 737 & 1,358 \\
\hline & NPF_SQRT &, 538 & 120 & ,404 & 4,486 & 000 & ,728 & 1,374 \\
\hline
\end{tabular}

a. Dependent Variable:

PROFITABILITAS_SQRT

Sumber: spss versi 16

Hasil dari tabel coefficients dengan uji multikoleniaritas bahwa hasil perhitungan tolerance kurang dari 1-10 yang berarti tidak ada korelasi antara variabel bebas independen, dan untuk hasil perhitungan nilai variance inflaction factor (VIF) juga menunjukan hasil antara 1-10 maka tidak terdapat multikoleniaritas antara variabel bebas independen. Jadi 
dapat di simpulkan untuk uji multikoleniaritas berdasarkan tabel di atas tidak terjadi multikoleniaritas.

Gambar Uji Heterokadisitas

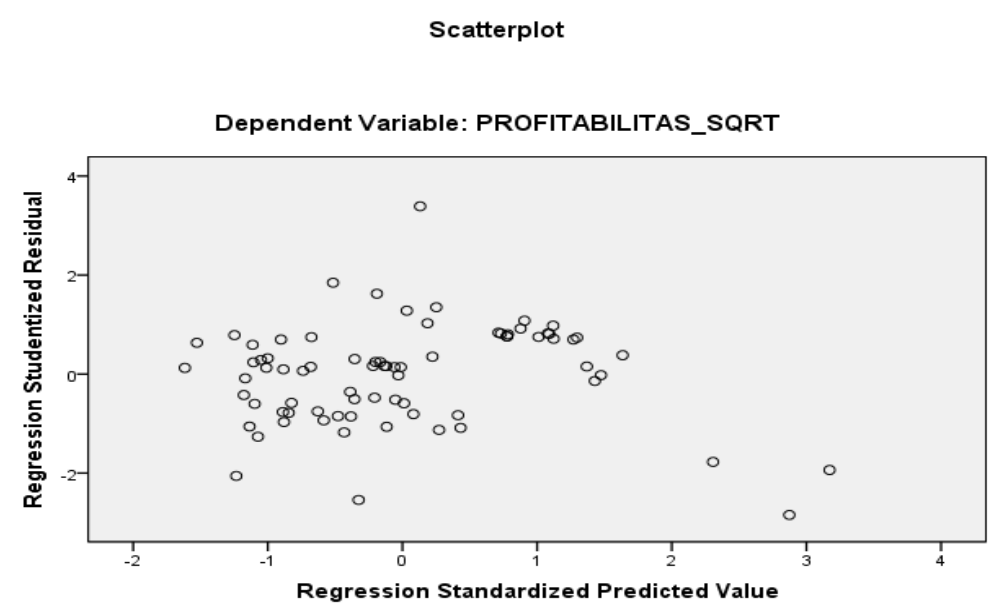

Heteroskedasitas menguji terjadi perbedaan variance residual suatu periode pengamatan yang lain. Cara memprediksi ada tidaknya heterokedasitas pada suatu model dapat di lihat pada pola gambar scatterplot gambar di atas terlihat bahwa titik-titik menyebar dan tidak membentuk pola tertentu yang jelas, sehingga dapat di simpulkan bahwa tidak terjadi heteroskedasitas.

Menurut V.Wiratna sujarweni (2016:231) menguji autokorelasi dalam suatu model bertujuan untuk mengetahui ada tidaknya korelasi antara variabel pengganggu pada periode tertentu dengan dengan variabel sebelumnya. Mendeteksi autokorelasi dengan menggunakan nilai durbin watson di bandingkan dengan Durbin Watson ( $d l d a n d u$ ). Kriteria jika $d u<d$ hitung < 4-du maka tidak terjadi autokorelasi. Tabel autokorelasi sebagai berikut:

Tabel Uji Autokorelasi

Model Summary ${ }^{b}$

\begin{tabular}{|l|r|r|r|r|r|}
\hline Model & \multicolumn{1}{|c|}{$\mathrm{R}$} & R Square & \multicolumn{1}{c|}{$\begin{array}{c}\text { Adjusted R } \\
\text { Square }\end{array}$} & $\begin{array}{c}\text { Std. Error of the } \\
\text { Estimate }\end{array}$ & Durbin-Watson \\
\hline 1 & $.672^{\mathrm{a}}$ & .452 & .429 & 2.88228 & 1.861 \\
\hline
\end{tabular}

a. Predictors: (Constant), NPF_SQRT, FDR_SQRT, BOPO_SQRT

Hasil dari tabel 4.5 dapat di lihat bahwa dengan menggunakan rumus transformasi untuk menghitung Durbin Watson menggunakan rumus sqrt maka jika nilai du $<\mathrm{d}$ hitung < 4-du tidak terjadi autokorelasi. Nilai Durbin Watson $(\mathrm{k}, \mathrm{n})$ jadi ( 3 variabel bebas dan $\mathrm{n} 76$ sampel) dengan memperoleh nilai du dan dl adalah 1.710 dan 1.546, maka nilai autokorelasi diantara $1.710<1,861<2,289$ jadi tidak terjadi autokorelasi.

Untuk regresi berganda dilakukan menguji pengaruh simultan dari beberapa $\mathrm{x}$ bebas terhadap satu variabel terikat yang berskala interval. Untuk menguji regresi berganda sebagai berikut: 
Tabel Uji Regresi Berganda

Coefficients $^{\mathrm{a}}$

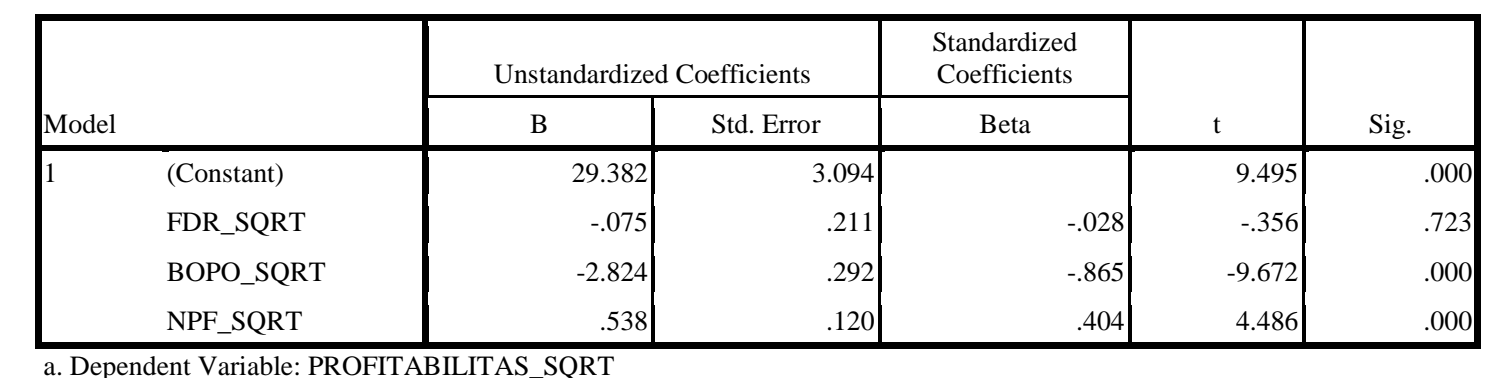

$$
\begin{aligned}
& Y=\alpha+\beta X+e \\
& Y=29,382-0,075 X 1-2,824 \times 2+0,538 \times 3
\end{aligned}
$$

Dimana : $\quad \mathrm{Y}=$ Profitabilitas

$$
\begin{aligned}
& \mathrm{a}=\text { constanta } \\
& \mathrm{X} 1=\mathrm{FDR} \\
& \mathrm{X} 2=\mathrm{BOPO} \\
& \mathrm{X} 3=\mathrm{NPF}
\end{aligned}
$$

Hasil dari tabel uji regresi berganda dapat diketahui bahwa constanta dari tabel 4.6 untuk persamaan diatas bernilai positif sebesar 29,382. Jadi untuk variabel bebas constanta besar nilai Y bernilai sebesar 29,382.

Tabel uji regresi berganda untuk variabel X1 bernilai negatif, adanya hubungan fungsional antara $\mathrm{X} 1$ dengan $\mathrm{Y}$ berbanding terbalik atau ( $\beta 1$ bernilai negatif). Regresi berganda variabel X1 sebesar -0,075 mengandung arti setiap FDR (Financing to Deposit) yang menyebabkan menurunnya nilai profitabilitas sebesar $-0,075$.

Tabel uji regresi berganda untuk variabel X2 bernilai negatif, adanya hubungan fungsional antara $\mathrm{X} 2$ dengan $\mathrm{Y}$ berbanding terbalik atau ( $\beta 2$ bernilai negatif). Regresi berganda variabel X2 sebesar -2,824 mengandung arti setiap BOPO (Biaya Operasional dan Pendapatan Operasional)yang menyebabkan menurunnya nilai profitabilitas sebesar -2,824.

Tabel uji regresi berganda untuk variabel X3 bernilai positif, adanya hubungan

\begin{tabular}{|c|c|c|c|c|c|c|}
\hline \multirow{2}{*}{\multicolumn{2}{|c|}{ Model }} & \multicolumn{2}{|c|}{ Unstandardized Coefficients } & \multirow{2}{*}{$\begin{array}{c}\begin{array}{c}\text { Standardized } \\
\text { Coefficients }\end{array} \\
\text { Beta }\end{array}$} & \multirow[b]{2}{*}{$\mathrm{t}$} & \multirow[b]{2}{*}{ Sig. } \\
\hline & & $\mathrm{B}$ & Std. Error & & & \\
\hline \multirow[t]{4}{*}{1} & (Constant) & 29.382 & 3.094 & & 9.495 & .000 \\
\hline & FDR_SQRT & -.075 & .211 & -.028 & -.356 & .723 \\
\hline & BOPO_SQRT & -2.824 & .292 & -.865 & -9.672 & .000 \\
\hline & NPF_SQRT & .538 & .120 & .404 & 4.486 & .000 \\
\hline
\end{tabular}
fungsional antara X3 dengan Y searah ( $\beta 3$ bernilai positif). Regresi berganda variabel X3 sebesar 0,538 mengandung arti setiap NPF (Non Perfoming Financing) yang menyebabkan menaiknya atau meningkatnya nilai profitabilitas sebesar 0,538 .

\section{Tabel Uji statistik $\mathbf{t}$}

Coefficients $^{\mathbf{a}}$

a. Dependent Variable: PROFITABILITAS_SQRT 
Berdasarkan hasil uji t pada tabel 4.7 bahwa nilai sig untuk pengaruh X1 terhadap Y adalah sebesar $0,723>0,05$ dan nilai t hitung $-0,356<\mathrm{t}$ tabel 1,993 , sehingga dapat di simpulkan bahwa tidak ada pengaruh yang terjadi antara variabel X1 terhadap Y.

Dari hasil uji t pada tabel 4.7 bahwa nilai sig untuk pengaruh $\mathrm{X} 2$ terhadap $\mathrm{Y}$ adalah sebesar $0,000<0,05$ dan nilai t hitung $-9,672>\mathrm{t}$ tabel 1,993, sehingga dapat di simpulkan bahwa ada pengaruh signifikan yang terjadi antara variabel X2 terhadap Y.

Dari hasil uji t pada tabel 4.7 bahwa nilai sig untuk pengaruh X3 terhadap Y adalah sebesar $0,000<0,05$ dan nilai t hitung 4,486 > t tabel 1,993, sehingga dapat di simpulkan bahwa ada pengaruh signifikan yang terjadi antara variabel X3 terhadap Y.

\section{Tabel Uji statistik F simultan}

\begin{tabular}{|c|c|c|c|c|c|c|}
\hline \multicolumn{7}{|c|}{ ANOVA $^{b}$} \\
\hline & & Sum of Squares & $\mathrm{df}$ & Mean Square & $\mathrm{F}$ & Sig. \\
\hline \multirow[t]{3}{*}{1} & Regression & 34,846 & 3 & \multirow{3}{*}{$\begin{array}{r}11,615 \\
, 357\end{array}$} & \multirow[t]{3}{*}{32,526} & \multirow[t]{3}{*}{, $000^{2}$} \\
\hline & Residual & 25,712 & 72 & & & \\
\hline & Total & 60,558 & 75 & & & \\
\hline
\end{tabular}

Berdasarkan signifikan output tabel 4.8 dapat di ketahui bahwa nilai signifikansi untuk variabel independen $\mathrm{X} 1, \mathrm{X} 2$ dan $\mathrm{X} 3$ secara simultan terhadap $\mathrm{Y}$ adalah sig sebesar $0,000<0,05$ dan nilai $\mathrm{F}$ hitung 32,526 $>\mathrm{F}$ tabel 2,730, sehingga dapat di simpulkan bahwa terdapat pengaruh X1,X2 dan X3 secara simultan terhadap Y.

Menurut Ghozali (2011:97) Koefisien determinasi $\left(\mathrm{R}^{2}\right)$ pada intinya mengukur seberapa jauh kemampuan model dan menerangkan variasi variabel dependen. Nilai koefisien determinasi antar 0-1. Nilai $\left(\mathrm{R}^{2}\right)$ yang kecil berarti kemampuan variabel-variabel independen dalam menjelaskan variasi variabel dependen sangat terbatas. Nilai yang mendekati satu berarti variabel-variabel inependen memberikan hampir semua informasi yang di butuhkan untuk memprediksi variasi variabel dependen.

Tabel Uji koefisien determinasi

Model Summary ${ }^{\mathrm{b}}$

\begin{tabular}{|c|c|c|c|c|}
\hline Model & $\mathrm{R}$ & R Square & Adjusted R Square & $\begin{array}{c}\text { Std. Error of the } \\
\text { Estimate }\end{array}$ \\
\hline 1 &, $717^{\mathrm{a}}$ &, 514 &, 494 & 3,19835 \\
\hline
\end{tabular}

a. Predictors: (Constant), NPF, FDR, BOPO

b. Dependent Variable: PROFITABILITAS

Berdasarkan hasil tabeluji koefisien korelasi (R) sebesar 0,717 yang menunjukkan hubungan antara X1,X2, dan X3 dengan Y. Koefisien determinasi (R2) menggunakan adjust $\mathrm{R}$ square sebesar 0,514, maka mengandung pengaruh pada variabel $\mathrm{X} 1, \mathrm{X} 2$, dan $\mathrm{X} 3$ secara simultan terhadap Y sebesar 51,4\% dan sisanya sebesar 48,6\% yang dijelaskan di luar model.

Dalam hasil statistik bahwa FDR (Financing deposit Ratio) tidak mempunyai pengaruh terhadap profitabilitas pada bank syariah. Dapat di lihat dari nilai sig untuk pengaruh X1 terhadap $\mathrm{Y}$ adalah sebesar 0,723 > 0,05 maka tidak mempunyai pengaruh terhadap profitabilitas pada bank syariah. FDR (Financing deposit to Ratio) merupakan salah satu rasio yang digunakan untuk mengukur suatu kemampuan bank dalam memenuhi 
likuiditas kepada dana pihak ketiga, dalam hal ini dapat di lihat bahwa semakin meningkatnya FDR menjadikan kurang efesien bank dalam memenuhi likuiditas kepada dana pihak ketiga. Penelitian ini hampir sesuai dengan Nasution, Sri mutiah (2017).

Dari hasil BOPO (Biaya Operasional dan Pendapatan Operasional merupakan rasio yang sering disebut rasio efesiensi yang digunakan untuk mengukur kemampuan manajemen bank dalam mengendalikkan biaya operasional terhadap pendapatan operasional. Semakin kecil rasio ini berarti semakin efisien biaya operasional yang dikeluarkan bank yang bersangkutan sehingga kemungkinan suatu bank dalam kondisi bermasalah semakin kecil.

Dalam dari hasil uji nilai sig untuk pengaruh X2 terhadap Y adalah sebesar 0,000< 0,05 dalam hal ini menunjukkan bahwa BOPO (Biaya Operasional dan pendapatan operasional berpengaruh signifikan terhadap profitabilitas pada bank umum syariah. Dengan nilai signifikan yang telah di tunjukkan oleh BOPO (Biaya operasional dan Pendapatan Operasional) maka semakin menurunnya biaya operasional terhadap pendapatan operasional hal ini menunjukkan bahwa manajemen bank efesien dalam menjalankan setiap aktivitas operasionalnya dengan ini mempunyai pengaruh yang meningkat dalam menjalankan operasi bank dan hal ini akan meningkatkan pendapatan atau profitabilitas yang di hasilkan oleh bank. Penelitian ini hampir sesuai dengan Nasution, sri muita (2017).

Berdasarkan Hasil Non Perfoming Financing Merupakan rasio antara pembiayaan yang bermasalah dengan total pembiayaan yang disalurkan oleh bank syariah. Semakin rendah nilai npf maka semakin baik profitabilitas suatu perbankkan. Dalam peningkatan NPF dapat mempengaruhi besaran keuntungan bank syariah. Dengan meningkatnya kredit yang bermasalah pada perbankkan syariah dalam hal ini berdampak pada tingginya resiko kredit yang di salurkan termasuk biaya tak tertagih.

Dari hasil uji nilai sig untuk pengaruh X3 terhadap Y adalah sebesar $0,000<0,05$ dan dalam hal ini bahwa NPF berpengaruh signifikan terhadap profitabilitas pada bank umum syariah. Dengan nilai signifkan yang telah di tunjukkan oleh NPF maka semakin kecil resiko pengembalian pembiayaan yang macet dari pihak nasabah kepada bank, maka hal ini menunjukkan bahwa semakin menurunya npf maka semakin efesien bank dalam menjalankan operasi bank dalam meningkatkan profitabilitas. Penelitian ini hampir sesuai dengan Lydia rahmadhini arifin (2016).

Berdasarkan hasil X1, X2 dan X3 secara simultan yang mempunyai pengaruh terhadap variabel dependen apabila nilai sig dalam uji $\mathrm{F}$ lebih kecil dari alpha (confidance interval), dengan hasil uji $\mathrm{F}$ (simultan) pada tabel di atas menunjukkan bahwa nilai sig sebesar $0,000<0,05$ sehingga dapat di simpulkan bahwa terdapat pengaruh $\mathrm{X} 1, \mathrm{X} 2$ dan $\mathrm{X} 3$ secara simultan terhadap Y. Dengan ini dapat di simpulkan bahwa Ha diterima.

\section{SIMPULAN}

Dari hasil pada pembahasan di atas, maka dapat di simpulkan bahwa FDR (Financing Deposit Ratio) tidak signifikan terhadap profitabilitas pada bank umum syariah. Nilai signifikan sebesar 0,723 lebih besar dari 0,05. Hal tersebut menunjukkan bahwa variabel FDR secara parsial tidak mempunyai pengaruh terhadap profitabilitas. Dari hasil penelitian ini sama dengan penelitian yang di lakukan oleh Nasution, Sri mutiah (2017) dan Ridho 
ilham putra wardana (2015). BOPO (Biaya Operasional dan Pendapatan Operasional) berpengaruh signifikan terhadap profitabilitas pada bank umum syariah. Nilai signifikan sebesar 0,000 lebih kecil dari 0,05. Hal tersebut menunjukkan bahwa variabel BOPO berpengaruh signifikan terhadap profitabilitas pada bank umum syariah secara parsial. Dari hasil penelitian ini sama dengan yang di lakukan oleh Nasution, Sri mutiah (2017) dan Ridho ilham putra wardana (2015). NPF (Non perfoming Financing) berpengaruh signifikan terhadap profitabilitas pada bank umum syariah. Nilai signifikan sebesar 0,000 lebih kecil dari 0.05. Hal tersebut menunjukkan bahwa variabel NPF berpengaruh signifikan terhadap profitabilitas pada bank umum syariah secara parsial. Dari hasil penelitian ini sama dengan yang di lakukan oleh Nasution, Sri mutiah (2017) dan Ridho ilham putra wardana (2015).

\section{DAFTAR PUSTAKA}

A. Wangsawidjaja, 2012, Pembiayaan Bank Syariah, Jakarta, PT. Gramedia Pustaka Utama. Antonio, Muhammad, 2002, Bank Syariah dan Teori ke Prakteknya, Jakarta, Gema Insan Press Tazkia Institute

Apandi Ahmad, 2015, Pengaruh Financing to deposit Ratio (FDR), Non perfoming financing (NPF), Retrun on Asset(ROA), dan capital Adequacy Ratio( CAR) terhadap pembiayaan mudharabah (Survay pada Bank Syariah yang listing di bursa efek Indonesia pada tahun 2009-2013), Skripsi jurusan Akuntansi, Universitas Widyatama.

Arfian Rahmadhini Lydia, Analisis faktor-faktor yang mempengaruhi tingkat bagi hasil simpanan mudharabah bank umum syariah di Indonesia, Skripsi Jurusan Manajemen Informasi Perbankkan Syariah, Universitas Islam Negeri Syarif Hidayatullah.

Budi ponco, 2008, Analisis Pengaruh CAR, NPL, BOPO, NIM, dan LDR Terhdap ROA pada Perusahaan Perbankkan yang Terdaaftar di BEI periode (2004-2007), Tesis, Unoversitas Diponogoro.

Fitriana Risya, Analisis pengaruh dana pihak ketiga (DPK), tingkat bagi hasil, financing deposite ratio(FDR) dan capital Adequacy Ratio( CAR) terhadap pembiayaan mudharabah, Skripsi jurusan Perbankkan Syariah, Universitas Islam Negeri Syarif Hidayatullah.

Gunawan Imam, 2016, Pengantar Statistika Inferensial, Jakarta,Bumi Aksara.

Gudono, 2012, Teori Organisasi, Yogyakarta, BPFE.

Ghozali Imam, 2011, Aplikasi Analisis Multivariate Dengan Program Spss, Semarang, Universitas Ponogoro.

Halim, Abdul dan Mamduh M.Hanafi, 2009, Analisis Laporan Keuangan, Yogyakarta, UUP STIM YKPN

Ismail,2016, perbankkan syariah, jakarta, Prenadamedia group

Kasmir, 2008, Bank dan Lembaga Keuangan lainnya, Jakarta, PT. Rajagrafindo Pesada

Latan, Hengky Dan Selva Tamalagi, 2013, Analisis Multivariate Teknik Dan Aplikasi Menggunakan Program IBM SPSS20,0,Bandung, ALVABETA,Cv

Lukman Dendawijaya, 2003, Manajemen Perbankan, Jakarta, Ghalia Indonesia 
Mutiah Sri, Nasution, Pengaruh retrun on assets (ROA), Financing to deposit ratio (FDR) dan biaya operasional atas pendapatan operasional (BOPO) terhadap tingkat bagi hasil deposito mudharabah dan tingkat pengembalian ekuitas pada bank umum syariah di Indonesia tahun 2010-2011, Skripsi Jurusan Akuntansi, Universitas Sumatera Utara.

Nurhayati Sri Wasilah, 2015 Akuntansi Syariah Di Indonesia, Jakarta Selatan, Salemba Empat

Pratiwi Dayinta Dhian, 2012, Pengaruh CAR, BOPO, NPF dan FDR terhadap Retrun on asset (ROA) bank umum syariah, Skripsi jurusan Ekonomi dan Bisnis Manajemen, Universitas Diponegoro Semarang.

Permata Dwi Inti Russely, Yaningwati Fransisca, Zahroh Z.A, 2014, Analisis pengaruh pembiayaan mudharabah dan musyarakah terhadap tingkat profitabilitas (retrun on equity) ( studi pada bank umum syariah yang terdaftar di bank Indonesia periode 20092012, Skripsi jurusan Iilmu Administrasi, Universitas Brawijaya Malang.

Pandia, Frianto, 2012, Manajemen Dana dan Kesehatan Bank, Jakarta, Rineka cipta

Sugiyono, 2013, Metode Penelitian Pendekatan Kuantitatif, Kualitatif, dan R\&D, Bandung, Alfabeta.

Umi Narimawati, 2008, Metodologi Penelitian Kualitatif dan Kuantitatif, Teori dan Aplikasi, Bandung, Agung Media

Wiratna Sujarweni.V, 2016 “Statistik Untuk Bisnis Dan Ekonomi”, Yogyakarta

Wiyono Slamet, 2013, Memahami Akuntansi Syariah Di Indonesia, Mitra Wacana Media.

Wardana Putra Ilham Ridhlo, Widyarti Tri Endang, Analisis pengaruh CAR, FDR, NPF, dan SIZE terhadap profitabilitas pada Bank umum syariahdi Indonesia, Skripsi jurusan Manajemen, Universitas Diponegoro Semarang. 